\title{
Erratum to: Investing in Low-Carbon Energy Systems
}

\author{
Venkatachalam Anbumozhi, Kaliappa Kalirajan, Fukunari Kimura \\ and Xianbin Yao
}

\section{Erratum to: \\ V. Anbumozhi et al. (eds.), Investing in Low-Carbon Energy Systems, DOI 10.1007/978-981-10-0761-3}

The book was inadvertently published with an error in the book title. The title should be Investing in Low-Carbon Energy Systems whereas it was given as Investing on Low-Carbon Energy Systems. The title has been updated with the correction.

The updated original online version for this book can be found at DOI 10.1007/978-981-10-0761-3.

V. Anbumozhi · F. Kimura

Economic Research Institute for ASEAN and East Asia (ERIA),

Jakarta, Indonesia

e-mail: v.anbumozhi@eria.org

K. Kalirajan $(\bowtie)$

Crawford School of Public Policy, Australian National University,

Canberra, Aust Capital Terr, Australia

e-mail: kpkalirajan@yahoo.com; kaliappa.kalirajan@anu.edu.au

F. Kimura

Faculty of Economics, Keio University, Tokyo, Japan

e-mail: fukunari.kimura@eria.org

X. Yao

Asian Development Bank, Manila, Philippines

e-mail: xyao@adb.org 